\title{
Parathyroid hormone-related peptide stimulates DNA synthesis and insulin secretion in pancreatic islets
}

\author{
M L Villanueva-Peñacarrillo, J Cancelas, $\mathrm{F}$ de Miguel $^{1}$, \\ A Redondo, A Valín ${ }^{1}$, I Valverde and $\mathbf{P}$ Esbrit ${ }^{1}$ \\ Department of Metabolism, Nutrition and Hormones, Fundación Jiménez Díaz, Madrid, Spain \\ ${ }^{1}$ Laboratory of Bone and Mineral Research, Fundación Jiménez Díaz, Madrid, Spain \\ (Requests for offprints should be addressed to P Esbrit, Laboratory of Bone and Mineral Research, Fundación Jiménez Díaz, Avda. Reyes Católicos, 2, \\ 28040 Madrid, Spain; Email: pesbrit@fjd.es)
}

\begin{abstract}
Parathyroid hormone (PTH)-related protein (PTHrP) is present in the pancreatic islet. Recent data in transgenic mice suggest that PTHrP might modulate islet mass and insulin secretion. In the present study, we assessed the effect of the N-terminal PTH-like region of PTHrP on DNA synthesis in isolated rat islets. PTHrP (1-34), between $1 \mathrm{pM}$ and $10 \mathrm{nM}$, for $48 \mathrm{~h}$ stimulated $\left[{ }^{3} \mathrm{H}\right]$ thymidine incorporation into rat islets. This effect was maximally induced, about $2 \cdot 5$-fold over control, by $10 \mathrm{pM}$ of this peptide, decreasing thereafter. In contrast, PTHrP (38-64) amide or PTHrP (107-139) were ineffective in increasing DNA synthesis in islets. Using reverse transcription followed by PCR, we confirmed that rat islets express PTHrP and the type I PTH/PTHrP receptor. Addition of a neutralizing anti-PTHrP antibody to the incubation medium of proliferating islets decreased islet
\end{abstract}

DNA synthesis by $30 \%$. The effect of a submaximal dose (30 pM) of PTHrP (1-34) on DNA synthesis in rat islets was abolished by $25 \mathrm{nM}$ bisindolylmaleimide I, a protein kinase $\mathrm{C}$ (PKC) inhibitor, but not by $25 \mu \mathrm{M}$ adenosine $3^{\prime}, 5^{\prime}$-cyclic monophosphorothioate, $\mathrm{Rp}$-isomer, a protein kinase A inhibitor. Moreover, $100 \mathrm{nM}$ phorbol-12myristate-13-acetate for $48 \mathrm{~h}$ also increased DNA synthesis 2-fold over controls in islets. PTHrP (1-34), at $100 \mathrm{nM}$, in contrast to $50 \mu \mathrm{M}$ forskolin or $10 \mathrm{mM} \mathrm{NaF}$, failed to affect adenylate cyclase activity in islet membranes. PTHrP, at $30 \mathrm{pM}$, was also found to increase 2 -fold insulin released into the islet-conditioned medium within $24-48 \mathrm{~h}$. Our results suggest that PTHrP is a modulator of pancreatic islet growth and/or function by a PKC-mediated mechanism.

Journal of Endocrinology (1999) 163, 403-408

\section{Introduction}

Parathyroid hormone-related protein (PTHrP) was initially identified as the main factor responsible for the paraneoplastic syndrome of humoral hypercalcemia of malignancy (Wysolmerski \& Broadus 1994). The PTHrP gene has subsequently been detected in a broad variety of normal tissues, including the pancreatic islet (Drucker et al. 1989, Asa et al. 1990, Gaich et al. 1993, Philbrick et al. 1996). In addition, genes for both the common type I PTH/PTHrP receptor (PTHR1) cloned in bone and renal cells and a $\mathrm{PTH}$-specific receptor are present in the pancreas (Abou-Samra et al. 1992, Usdin et al. 1995). Using radiolabeled binding techniques, PTHrP receptors having low affinity compared with the PTHR1, have been found in cultured rat insulinoma (RIN) cells (Gaich et al. 1993). These cells have no cAMP response to PTHrP (1-36) but do display a rapid and sensitive intracellular calcium response to either this peptide or PTH (1-34) (Gaich et al. 1993). Thus, a high-affinity PTH/PTHrP receptor associated with intracellular calcium transience, undetected by using binding techniques, is likely to be present in RIN cells. Collectively, current findings indicate that various receptor types recognizing $\mathrm{PTHrP}$ and/or PTH are present in the pancreas.

Treatment of RIN cells with the islet differentiation agent sodium butyrate rapidly induces the transcription of the PTHrP gene (Streutker \& Drucker 1991). In addition, recent studies in transgenic mice overexpressing PTHrP in the pancreatic $\beta$ cells have shown lower fasting and postprandial plasma glucose, and higher plasma insulin concentration, compared with those of their normal littermates (Vasavada et al. 1996, Porter et al. 1998). Furthermore, insulin production was increased in the pancreas of these transgenic animals, as a result of an increased islet mass (Vasavada et al. 1996, Porter et al. 1998). Thus, PTHrP might act as an auto/paracrine factor in the pancreatic islet, as it does in a variety of other tissues (Philbrick et al. 1996).

In the present study, we found that PTHrP (1-34) stimulates DNA synthesis in isolated islets from adult rats, expressing PTHrP and the PTHR1, apparently by 
a protein kinase $\mathrm{C}$ (PKC)-mediated mechanism. In addition, this effect appears to be associated with an increased insulin release into the islet incubation medium.

\section{Materials and Methods}

\section{Reagents}

Collagenase P from Clostridium histolyticum was from Boehringer (Mannheim, Germany). Forskolin, 3-isobutyl1-methylxantine (IBMX), NaF, human PTHrP (1-34) and human PTHrP (107-139) were from Sigma (St Louis, MO, USA). Human PTHrP (38-64) amide was from Peninsula (Belmont, CA, USA). Fetal calf serum (FCS) was from Biochrom KG (Berlin, Germany). Adenosine 3',5'-cyclic monophosphorothioate, Rp-isomer (RpcAMPS) was supplied by Biolog Life Science Institute (Bremen, Germany). Bisindolylmaleimide I (BIM) and phorbol-12-myristate-13-acetate (PMA) were from Calbiochem (San Diego, CA, USA). Rat insulin was from Linco (St Charles, MO, USA). Ham's F10 medium was from Seromed (Biochrom KG).

\section{Pancreatic islets}

Pancreatic islets were isolated from normal female Wistar rats (200-250 g body weight) by collagenase digestion, as previously described (Malaisse-Lagae \& Malaisse 1984).

\section{Pancreatic islet plasma membranes}

A group of 800 islets was homogenized in a Potter homogenizer (ten strokes), in $100 \mu \mathrm{l} 25 \mathrm{mM}$ Tris- $\mathrm{HCl}$, $\mathrm{pH} 7 \cdot 5$, containing $5 \mathrm{mM} \mathrm{MgCl}, 0.6 \mathrm{mM}$ EGTA and $1.1 \mathrm{mM}$ dithiothreitol, at $4{ }^{\circ} \mathrm{C}$. The resulting debris was separated by sedimentation at $100 \mathrm{~g}$, at $4{ }^{\circ} \mathrm{C}$, and discarded; the supernatant, containing plasma membranes, was used to determine its adenylate cyclase activity.

\section{DNA synthesis}

Groups of 50 islets were cultured, under sterile conditions, in Ham's F10 medium $(6 \cdot 1 \mathrm{mM}$ D-glucose) with $1 \%$ FCS and antibiotics, in the absence (control) or presence of either different PTHrP peptides or $100 \mathrm{nM}$ PMA, with or without $25 \mathrm{nM}$ BIM, a PKC inhibitor (Toullec et al. 1991), or $25 \mu \mathrm{M}$ RpcAMPS, a protein kinase A (PKA) inhibitor (Wang et al. 1992), for $24 \mathrm{~h}$ at $37^{\circ} \mathrm{C}$; the two latter agonists were added $1 \mathrm{~h}$ before PTHrP (1-34). The islets were then further cultured for $24 \mathrm{~h}$ in fresh medium containing the same agents and $1.5 \mu \mathrm{Ci} / \mathrm{ml}\left[{ }^{3} \mathrm{H}\right]$ thymidine $(87 \mathrm{Ci} / \mathrm{mmol}$, Amersham International plc, Amersham, Bucks, UK). Islet DNA was then precipitated with $4 \%$ $\mathrm{HClO}_{4}$ at $4{ }^{\circ} \mathrm{C}$, separated by filtration (Glass Microfiber Filters GF/C, Whatman, Maidstone, Kent, UK), and $\beta$-counted (Gallo et al. 1986). In parallel experiments, $\left[{ }^{3} \mathrm{H}\right]$ thymidine was not added, and islet function was studied at the end of the $48 \mathrm{~h}$ incubation period, by measuring the insulin response to D-glucose $(2 \cdot 8$ and $16.7 \mathrm{mM}$ ) for $60 \mathrm{~min}$ (Malaisse-Lagae \& Malaisse 1984). After incubations, the islet-conditioned medium was collected, and stored at $-20^{\circ} \mathrm{C}$ for insulin determination. In order to evaluate the effect of anti-PTHrP antibodies on islet cell proliferation, islets were incubated for $48 \mathrm{~h}$ in culture medium with $1-10 \% \mathrm{FCS}$, and $7 \mu \mathrm{g} / \mathrm{ml}$ of either affinity-purified anti-PTHrP neutralizing antibody C7 or nonimmunogenic rabbit IgG (Valín et al. 1997), and $\left[{ }^{3} \mathrm{H}\right]$ thymidine incorporation into islet DNA was measured as described above.

\section{Adenylate cyclase activity}

Adenylate cyclase activity was determined in isolated islet plasma membranes, as described (Valverde et al. 1979). Aliquot samples $(40 \mu \mathrm{l})$ of the plasma membrane preparations (1.4-1.9 $\mu \mathrm{g}$ protein (Lowry et al. 1951)) were added to $35 \mu \mathrm{l}$ of a reaction mixture containing $70 \mu \mathrm{M}$ ATP, $5 \mathrm{mM} \mathrm{MgCl} 2,25 \mathrm{mM}$ Tris- $\mathrm{HCl}$ and $0.5 \mathrm{mM}$ IBMX, without (control) or with $100 \mathrm{nM}$ PTHrP (1-34), $50 \mu \mathrm{M}$ forskolin or $10 \mathrm{mM} \mathrm{NaF}$. After $60 \mathrm{~min}$ at $37^{\circ} \mathrm{C}$, the reaction was stopped with ethanol (final concentration $65 \%$ ). After centrifugation at $1700 \mathrm{~g}$ for $15 \mathrm{~min}$, at $4{ }^{\circ} \mathrm{C}$, aliquot samples $(365 \mu \mathrm{l})$ of the supernatants were vacuumdried, and then resuspended in $120 \mu$ lof assay buffer for cAMP determination (RIANEN cAMP; Dupont, Brussels, Belgium).

\section{$R N A$ extraction and reverse transcription-PCR (RT-PCR)}

Total RNA was extracted from rat islets using guanidinium thiocyanate-phenol-chloroform extraction (Chomczynski \& Sacchi 1987). Total RNA aliquots were added to a reaction mixture containing $1 \mathrm{mM} \mathrm{MgSO}_{4}$, $0.2 \mathrm{mM}$ of each dNTP, $0.1 \mathrm{U} / \mu \mathrm{l}$ avian myeloblastosis virus (AMV) reverse transcriptase, $0 \cdot 1 \mathrm{U} / \mu \mathrm{l}$ thermostable DNA polymerase from Thermus flavus (Access RT-PCR System; Promega, Madison, WI, USA), and $1 \mu \mathrm{M}$ specific primers: 5'-TGCAGCGGAGACTGGTTCAG-3' (sense) and $5^{\prime}$-CCTCGTCGTCTGACCCAAA-3' (antisense) (PTHrP); and 5'-GATGCGGACGATGTCTTTACC-3' (sense) and 5'-GGCGGTCAAATACCTCC-3' (antisense) (PTHR1).

Using these primers, PCR amplification yields products of $301 \mathrm{bp}$ (PTHrP) or $483 \mathrm{bp}$ (PTHR1) (Li et al. 1996, García-Ocaña et al. 1998). Total RNA and the primers were preincubated for $5 \mathrm{~min}$ at $65^{\circ} \mathrm{C}$. Then the reaction mixture was incubated for $45 \mathrm{~min}$ at $48{ }^{\circ} \mathrm{C}$, and $2 \mathrm{~min}$ at $95^{\circ} \mathrm{C}$, followed by 35 cycles of $1 \mathrm{~min}$ at $95^{\circ} \mathrm{C}, 1 \mathrm{~min}$ at $58^{\circ} \mathrm{C}$, and $2 \mathrm{~min}$ at $68^{\circ} \mathrm{C}$, with a final extension of $7 \mathrm{~min}$ at $68^{\circ} \mathrm{C}$. Negative controls without AMV transcriptase were usually included in our RT-PCR system, and 
amplification of glyceraldehyde 3-phosphate dehydrogenase, as a constitutive gene control, with specific primers was also performed (García-Ocaña et al. 1998, Largo et al. 1999). In addition, total RNA from rat kidney cortex, containing PTHrP and PTHR1 mRNAs (Largo et al. 1999), was also coamplified using the same primers described above, as a positive control. The PCR products were separated on $1.5 \%$ agarose gels, and bands were visualized by ethidium bromide staining. The specific PCR products were purified by adsorption to silica (Geneclean Bio 101, La Jolla, CA, USA), and subsequently reamplified using the same protocol described above, using 30 cycles. The identities of the PCR products were confirmed by sequencing with a dye-terminator cycle-sequencing kit (Perkin-Elmer, Branchburg, NJ, USA), using Taq FS DNA polymerase. Sequences were resolved on an ABI PRISM 377 automatic sequencer (Perkin-Elmer).

\section{Insulin release}

Insulin was measured in the islet incubation medium by RIA, using rat insulin as standard, and a guinea-pig anti-insulin serum developed in our laboratory, as previously described (Valverde et al. 1988).

\section{Statistical analysis}

Results are expressed as mean \pm S.E.M. (number of observations). Statistical significance, reported as $P<0 \cdot 05$, was assessed by unpaired $t$-test.

\section{Results}

PTHrP(1-34), from $1 \mathrm{pM}$ to $10 \mathrm{nM}$, for $48 \mathrm{~h}$ was found to increase $\left[{ }^{3} \mathrm{H}\right]$ thymidine incorporation into rat islets in medium with $6.1 \mathrm{mM}$ glucose (Fig. 1). This effect was maximal at $10 \mathrm{pM}$ PTHrP (1-34), decreasing thereafter (Fig. 1). In contrast, PTHrP (38-64) and PTHrP (107139), both at $10 \mathrm{pM}$, failed to stimulate islet DNA synthesis for the same time period.

We obtained PCR products in rat islets identical to those found in rat kidney, indicating the presence of PTHrP and PTHR1 mRNA (Fig. 2). In order to assess a possible autocrine effect of PTHrP on pancreatic islets, we added an anti-PTHrP antibody to the islet incubation medium in the presence of $10 \%$ FCS. The presence of this antibody significantly decreased the 10\% FCSstimulated $\left[{ }^{3} \mathrm{H}\right]$ thymidine incorporation into islets from $398 \pm 36$ d.p.m. to $276 \pm 69$ d.p.m. $(P<0 \cdot 025)$; while it was $407 \pm 15$ d.p.m., in the presence of nonimmunogenic rabbit $\operatorname{IgG}$, compared with $159 \pm 32$ d.p.m. in the $1 \%$ FCS control $(n=4, P<0 \cdot 01)$, after $48 \mathrm{~h}$ incubation.

We also evaluated the putative role of PKC and PKA in the PTHrP (1-34)-stimulatory effect on DNA synthesis

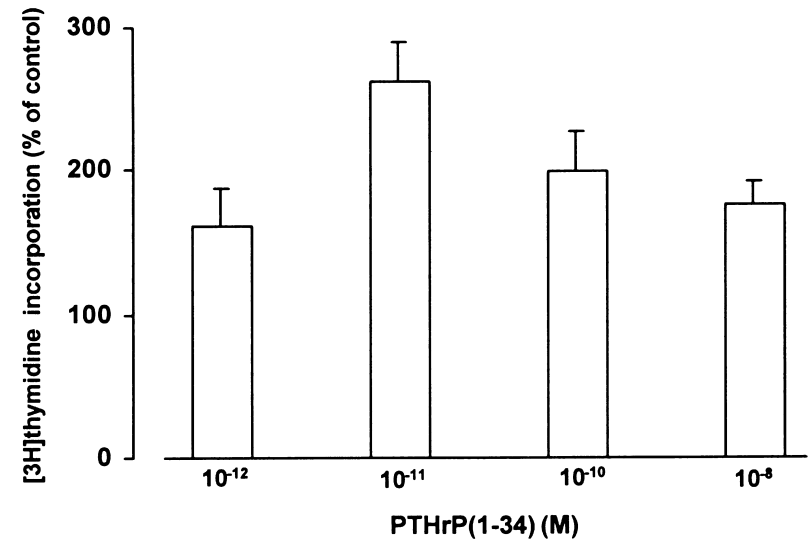

Figure 1 Dose-dependent effect of PTHrP (1-34) on $\left[{ }^{3} \mathrm{H}\right]$ thymidine incorporation into DNA in isolated rat islets after $48 \mathrm{~h}$ stimulation. Values are mean \pm S.E.M. of four to nine measurements. $P<0 \cdot 05$ or lower, at each PTHrP (1-34) dose tested, compared with nonstimulated control $(100 \%$, or $107 \pm 29$ d.p.m./tube).

into rat islets. We found that $25 \mathrm{nM}$ BIM, a PKC inhibitor (Toullec et al. 1991), in contrast to $25 \mu \mathrm{M}$ RpcAMPS, a PKA inhibitor (Wang et al. 1992), abolished this effect induced by a submaximnal dose (30 pM) of PTHrP (1-34) (Fig. 3); neither BIM nor RpcAMPS, when tested alone, had any significant effect on islet DNA synthesis (Fig. 3). The inhibitory effect of BIM on the stimulated DNA synthesis induced by PTHrP (1-34) was not associated with an impaired islet function, since preincubation with BIM for $48 \mathrm{~h}$ did not significantly affect the subsequent islet insulin secretion for $1 \mathrm{~h}$, which was: $146 \pm 6 \%$ (without BIM) and $136 \pm 1 \%$ (with BIM) in the presence of $16.7 \mathrm{mM}$ glucose, compared with the corresponding control values in the presence of $2.8 \mathrm{mM}$ glucose $(100 \%)$ :

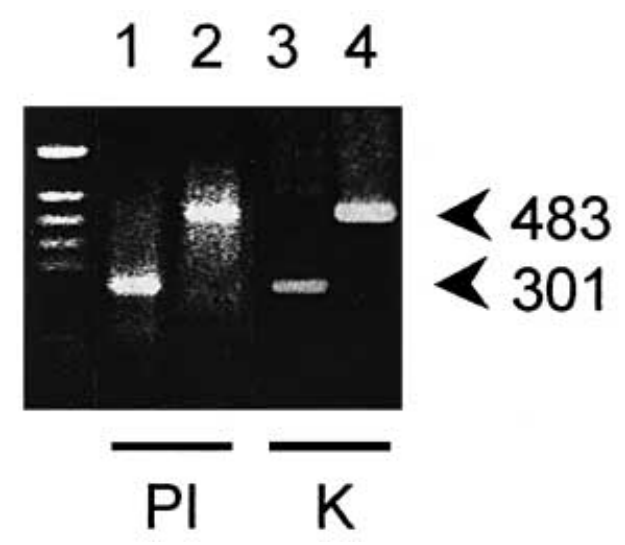

Figure 2 PTHrP (lanes 1 and 3) and PTHR1 (lanes 2 and 4) mRNA in rat pancreatic islets (PI) and rat kidney (K). RT-PCR was carried out with specific primers, and the corresponding PCR products were reamplified, using the Access RT-PCR System (Promega). PCR products were electrophoresed on 1.5\% agarose gel. DNA markers are shown in the first column on the left. 


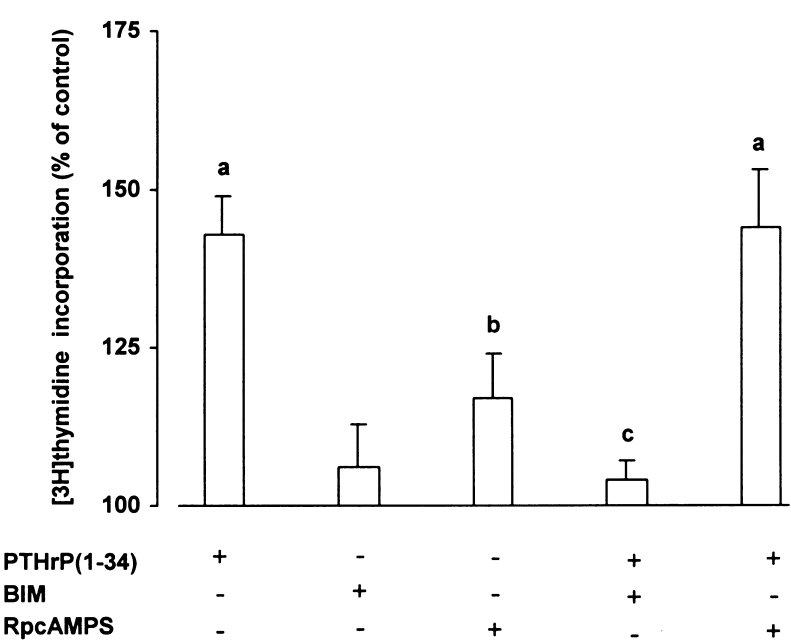

Figure 3 Effect of $25 \mathrm{nM}$ BIM (PKC inhibitor) and $25 \mu \mathrm{M}$ RpcAMPS (PKA inhibitor) on the DNA synthesis-stimulatory effect of $30 \mathrm{pM}$ PTHrP (1-34) in isolated rat islets for $48 \mathrm{~h}$. The inhibitors were added $1 \mathrm{~h}$ before PTHrP (1-34) addition. Values are mean \pm S.E.M. of four to six measurements. a, $P<0 \cdot 01$, compared with nonstimulated control (100\%, or $265 \pm 44$ d.p.m./tube); b, $P<0 \cdot 01$, compared with RpcAMPS + PTHrP (1-34); c, $P<0 \cdot 001$, compared with PTHrP 1-34) alone.

$362 \pm 36 \mathrm{pg} /$ islet (without BIM) or $475 \pm 51 \mathrm{pg} /$ islet (with BIM) (mean \pm s.E.M., corresponding to two independent experiments performed in six replicates). Furthermore, $100 \mathrm{nM}$ PMA, a PKC stimulator (Gagnon et al. 1993), also significantly stimulated islet DNA synthesis $(190 \pm 22 \%$ of control; $n=4, P<0 \cdot 05)$. PTHrP $(1-34)$, at $100 \mathrm{nM}$, failed to affect adenylate cyclase, while either $50 \mu \mathrm{M}$ forskolin or $10 \mathrm{mM} \mathrm{NaF}$ stimulated about 3-fold over control this enzymatic activity, in rat islet membranes (Fig. 4).

PTHrP (1-34), at $30 \mathrm{pM}$, induced an increase of insulin released into the islet culture medium after both subsequent $24 \mathrm{~h}$ time periods, which was: $279 \pm 33$ and $198 \pm 29 \%$ respectively, of control $(174 \pm 20 \mathrm{pg} /$ islet $)$ $(n=4, P<0 \cdot 05)$.

\section{Discussion}

In the present study, we found that both $\mathrm{N}$-terminal PTHrP and PTH, at pM doses, stimulate DNA synthesis in isolated rat islets. In contrast, other middle and C-terminal PTHrP fragments failed to affect DNA synthesis in islets. Consistent with previous findings, using immunohistochemistry and/or Northern blot analysis, in human and rat islets (Drucker et al. 1989, Asa et al. 1990, Gaich et al. 1993, Usdin et al. 1995), we have detected PTHrP and PTHR1 mRNA, by RT-PCR, in adult rat islets. In addition, we found that the presence of an anti-PTHrP neutralizing antibody decreased rat islet DNA synthesis. A recent study in islets isolated from neonatal

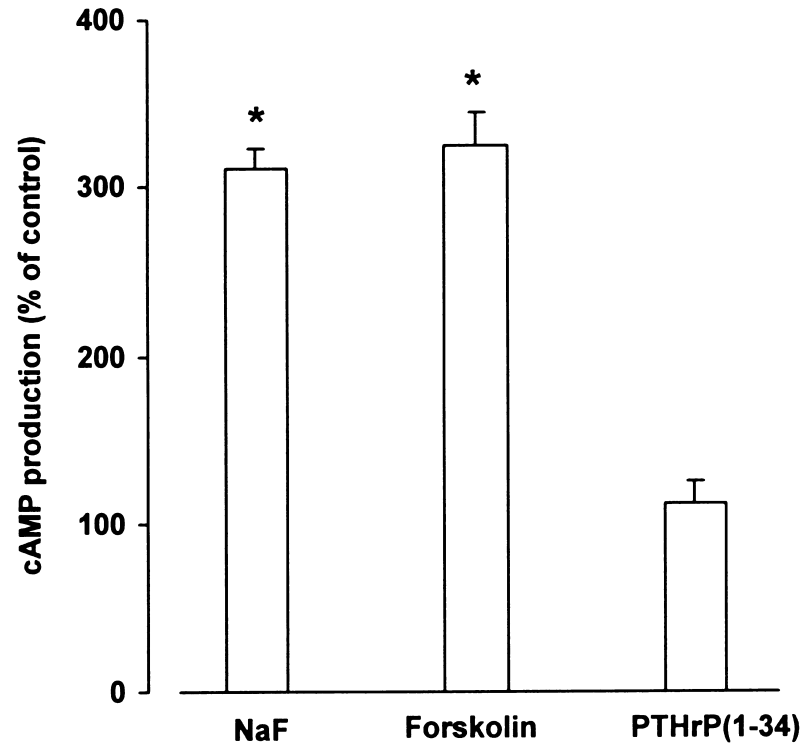

Figure 4 Effect of $100 \mathrm{nM}$ PTHrP (1-34), $10 \mathrm{mM} \mathrm{NaF}$, and $50 \mu \mathrm{M}$ forskolin, on adenylate cyclase activity in isolated rat islet plasma membranes. Islet membranes were obtained from homogenized islets after centrifugation at $100 \mathrm{~g}$. Adenylate cyclase activity was determined in aliquot samples of the supernatant incubated in the presence of ATP and the agonists for $1 \mathrm{~h}$ at $37^{\circ} \mathrm{C}$. Produced CAMP was measured by RIA. Values are mean \pm S.E.M. of three to seven experiments. ${ }^{*} P<0 \cdot 001$, compared with nonstimulated control.

rats failed to find a significant increase in islet proliferation rate, estimated as percent bromodeoxyuridine-positive nuclei, after continuous treatment with different PTHrP peptides (Porter et al. 1998). The reason for these discrepancies is unknown. However, using islets from adult rats, and $\left[{ }^{3} \mathrm{H}\right]$ thymidine incorporation to assess islet proliferation, we observed that higher PTHrP (1-34) concentrations, in the range of those tested in the aforementioned study (Porter et al. 1998), were less stimulatory of islet DNA synthesis than lower doses.

Previous reports in mice overexpressing PTHrP in the pancreatic islets demonstrated an increased islet mass associated with islet hyperplasia (Vasavada et al. 1996, Porter et al. 1998). These animals, opposite to PTHrPoverproducing tumor hosts, had neither hypercalcemia nor high plasma PTHrP (Wysolmerski \& Broadus 1994, Vasavada et al. 1996). These in vivo studies and the in vitro results herein support the concept that PTHrP in the pancreatic islets is an autocrine factor inducing islet proliferation.

Our results suggest that the effect of PTHrP (1-34) on islet DNA synthesis depends on PKC activation. In this regard, PTHrP (1-34), at pM concentration, has been shown to induce a peak of PKC activation in other cells (Gagnon et al. 1993, Whitfield et al. 1994). Moreover, PKC activation appears to be a mediator for the mitogenic effects 
of the N-terminal region of PTHrP and PTH in various cell types (Sömjen et al. 1990, Jouishomme et al. 1994, GarcíaOcaña et al. 1995).

We found that, in contrast to the common pattern of signaling through PTHR1, PTHrP (1-34) failed to increase cAMP in rat islets. This is consistent with previous findings on RIN cells displaying a cytosolic calcium response, but not a cAMP response, to PTHrP (1-36), detectable at $1 \mathrm{pM}$ (Gaich et al. 1993). Highaffinity binding sites for this peptide were not detected in these cells (Gaich et al. 1993). In this regard, the presence of a sensitive intracellular calcium response in the absence of high-affinity binding sites for N-terminal PTHrP has also been reported to occur in squamous carcinoma cells and keratinocytes (Orloff et al. 1992). Recent studies suggest that these cells appear to express a PTH/PTHrP receptor different from, but partially homologous to, the PTHR1 (Orloff et al. 1995). Whether such a receptor is present in both RIN cells and rat islets or, alternatively, PTHR 1 are of low abundance in these cells, and then undetected by radiolabeled binding techniques but revealed by mRNA analysis, deserves further studies.

PTHrP (38-64) amide was found to be ineffective in altering islet DNA synthesis. Recently, it has been demonstrated that PTHrP (38-94) amide, a PTHrP fragment produced and secreted by RIN cells, is unable to stimulate adenylate cyclase but induces cytosolic calcium increments in these cells (Wu et al. 1996). This effect is thought to be mediated by a PTHrP (67-86)-specific receptor similar to that identified in squamous carcinoma cells (Orloff et al. 1996). Our data do not allow us to conclude that such a receptor is present in pancreatic islets.

A recent report has shown that the insulin response to glucose of perifused islets from PTHrP-overexpressing mice is similar to that of normal islets (Vasavada et al. 1996). In contrast, Fadda et al. (1990) previously reported that PTH (1-34), in the $\mu \mathrm{M}$ range, triggered a rapid increase in glucose-induced insulin release by adult rat islets. This effect appeared to depend on a rise in cytosolic calcium, leading to a secondary PKC activation (Fadda et al. 1990). Our data herein are consistent with the latter findings, since the stimulatory effect of PTHrP (1-34) on islet DNA synthesis was found to be associated with an increased insulin secretion into the islet culture medium.

PTHrP does not appear to be a developmental factor in the islet, since homozygous PTHrP knockout mice have anatomically normal islets at birth (Karaplis et al. 1994). However, taken together, the bulk of previous studies and the present one support the concept that PTHrP is involved in the regulation of postnatal islet growth and/or function.

\section{Acknowledgements}

This work was supported by grants from Dirección General de Investigación Científica y Técnica (DGICYT,
95/0048) and Fondo de Investigación Sanitaria (FIS, 96/1383, 96/1167 and 98/1230). We are grateful to Dr A Díaz (DNA Automatic Sequencer Laboratory, Centro de Investigaciónes Biologicas, Consejo Superior de Investigaciónes Cientificas, Madrid) for sequencing the PCR products, and to Dr R Bosch (Department of Physiology, Alcalá University, Madrid) for providing us with the primers for PTHR1. J C and A V are research fellows of Fundación Conchita Rábago. A R and F M are research fellows of Ministerio de Educación y Cultura and Comunidad Autónoma de Madrid respectively. We also thank E Martín-Crespo for skillful technical assistance.

\section{References}

Abou-Samra A-B, Jüppner H, Force T, Freeman MW, Kong X-F, Schipani E, Ureña P, Richards J, Bonventre JV, Potts JT Jr, Kronenberg HM \& Segre GV 1992 Expression cloning of a common receptor for parathyroid hormone and parathyroid hormone-related peptide for rat osteoblast-like cells: a single receptor stimulates intracellular accumulation of both cAMP and inositol trisphosphates and increases intracellular free calcium. Proceedings of the National Academy of Sciences of the USA $\mathbf{8 9}$ 2732-2736.

Asa SL, Henderson J, Goltzman D \& Drucker DJ 1990 Parathyroid hormone-like peptide in normal and neoplastic human endocrine tissues. Journal of Clinical Endocrinology and Metabolism 71 1112-1118.

Chomczynski P \& Sacchi N 1987 Single step method of RNA isolation by acid guanidinium thiocyanate - phenol-chloroform extraction. Analytical Biochemistry 162 156-159.

Drucker DJ, Asa SL, Henderson J \& Goltzman D 1989 The parathryoid hormone-like peptide (PLP) gene is expressed in the normal and neoplastic human endocrine pancreas. Molecular Endocrinology 3 1589-1595.

Fadda GZ, Akmal M, Lipson LG \& Massry SG 1990 Direct effect of parathyroid hormone on insulin secretion from pancreatic islets. American Journal of Physiology 258 E975-E984.

Gagnon L, Jouishomme H, Whitfield J, Durkin JP, MacLean S, Neugebauer W, Willick G, Rixon RH \& Chakravarthy B 1993 Protein kinase C-activating domains of parathyroid hormone-related protein. Journal of Bone and Mineral Research 8 497-503.

Gaich G, Orloff JJ, Atillasoy EJ, Burtis, WJ, Ganz MB \& Stewart AF 1993 Amino-terminal parathyroid hormone-related protein: specific binding and cytosolic calcium responses in rat insulinoma cells. Endocrinology 132 1402-1409.

Gallo CJ, Koza RA \& Herbst EJ 1986 Polyamines and HeLa-cell DNA replication. Biochemical Journal 238 37-42.

García-Ocaña A, de Miguel F, Peñaranda C, Albar JP, Sarasa JL \& Esbrit P 1995 Parathyroid hormone-related protein is an autocrine modulator of rabbit proximal tubule cell growth. Journal of Bone and Mineral Research 10 1875-1884.

García-Ocaña A, Gómez-Casero E, Peñaranda C, Sarasa JL \& Esbrit P 1998 Cyclosporine increases renal parathyroid hormone-related protein expression in vivo in the rat. Transplantation 65 860-863.

Jouishomme H, Whitfield JF, Gagnon L, Maclean S, Isaacs R, Chakravarthy B, Durkin J, Neugebauer W, Willick G \& Rixon RH 1994 Further definition of the protein kinase C activation domain of the parathyroid hormone. Journal of Bone and Mineral Research 9 943-949.

Karaplis AC, Luz A, Glowacki J, Bronson RT, Tybulewicz VLJ, Kronenberg HM \& Mulligan RC 1994 Lethal skeletal dysplasia from targeted disruption of the parathyroid hormone-related peptide gene. Genes and Development 8 277-289. 
Largo R, Gómez-Garre D, Santos S, Peñaranda C, Blanco J, Esbrit P \& Egido J 1999 Renal expression of parathyroid hormone-related protein $(\mathrm{PTHrP})$ and $\mathrm{PTH} / \mathrm{PTHrP}$ receptor in a rat model of tubulointerstitial damage. Kidney International 55 82-90.

Li H, Seitz PK, Selvanayagam P, Rajaraman S \& Cooper CW 1996 Effect of endogenously produced parathyroid hormone-related peptide on growth of a human hepatoma cell line (Hep G2). Endocrinology 137 2367-2374.

Lowry OH, Rosebough NR, Farr AL \& Randall RJ 1951 Protein measurement with the Folin phenol reagent. Journal of Biological Chemistry 193 265-275.

Malaisse-Lagae F \& Malaisse WJ 1984 Insulin release by pancreatic islets. In Methods in Diabetes Research, vol 1, pp 147-152. Eds J Larner \& SL Pohl. New York: John Wiley.

Orloff JJ, Ganz MB, Ribaudo AE, Burtis WJ, Reiss M, Milstone LM \& Stewart AF 1992 Analysis of PTHrP binding and signal transduction mechanisms in benign and malignant squamous cells. American Journal of Physiology 262 E599-E607.

Orloff JJ, Kats Y, Ureña P, Schipani E, Vasavada RC, Philbrick WM, Behal A, Abou-Samra A-B, Segre GV \& Jüppner H 1995 Further evidence for a novel receptor for amino-terminal parathyroid hormone-related protein on keratinocytes and squamous carcinoma cell lines. Endocrinology 136 3016-3023.

Orloff JJ, Ganz MB, Nathanson MH, Moyer MS, Kats Y, Mitnick M, Behal A, Gasalla-Herraiz J \& Isales C 1996 A midregion parathyroid hormone-related peptide mobilizes cytosolic calcium and stimulates formation of inositol trisphosphate in a squamous carcinoma cell line. Endocrinology 137 5376-5385.

Philbrick WM, Wysolmerski JJ, Galbraith S, Holt E, Orloff JJ, Yang KH, Vasavada RC, Weir EC, Broadus AE \& Stewart AF 1996 Defining the roles of parathryoid hormone-related protein in normal physiology. Physiological Reviews 76 127-173.

Porter SE, Sorenson RL, Dann P, García-Ocaña A, Stewart AF \& Vasavada RC 1998 Progressive pancreatic islet hyperplasia in the islet-targeted, parathyroid hormone-related protein-overexpressing mouse. Endocrinology 139 3743-3751.

Sömjen D, Binderman I, Schlüter K-D, Wingender E, Mayer H \& Kaye AM 1990 Stimulation by defined parathyroid hormone fragments of cell proliferation in skeletal-derived cell cultures. Biochemical Journal 272 781-785.

Streutker C \& Drucker DJ 1991 Rapid induction of parathyroid hormone-like peptide gene expression by sodium butyrate in a rat islet cell line. Molecular Endocrinology 5 703-708.

Toullec D, Pianetti P, Coste H, Bellevergue P, Grand-Perret T, Ajakane M, Baudet V, Boissin P, Boursier E, Loriolle F, Duhamel L, Charon D \& Kirilovsky J 1991 The bisindolylmaleimide GF
109203X is a potent and selective inhibitor of protein kinase C. Journal of Biological Chemistry 266 15771-15781.

Usdin TB, Gruber C \& Bonner TI 1995 Identification and functional expression of a receptor selectively recognizing parathyroid hormone, the PTH2 receptor. Journal of Biological Chemistry 270 15455-15458.

Valín A, García-Ocaña A, de Miguel F, Sarasa JL \& Esbrit P 1997 Antiproliferative effect of the C-terminal fragments of parathyroid hormone-related protein, PTHrP-(107-111) and (107-139), on osteoblastic osteosarcoma cells. Journal of Cellular Physiology 170 209-215.

Valverde I, Vandermeers A, Anjaneyulu R \& Malaisse WJ 1979 Calmodulin activation of adenylate cyclase in pancreatic islets. Science 205 225-227.

Valverde I, Barreto M \& Malaisse W J 1988 Stimulation by D-glucose of protein biosynthesis in tumoral insulin-producing cells (RINm5F line). Endocrinology 122 1443-1448.

Vasavada RC, Cavaliere C, D'Ercole AJ, Dann P, Burtis WJ, Madlener AL, Zawalich K, Zawalich W, Philbrick W \& Stewart AF 1996 Overexpression of parathyroid hormone-related protein in the pancreatic islets of transgenic mice causes islet hyperplasia, hyperinsulinemia, and hypoglycaemia. Journal of Biological Chemistry 271 1200-1208.

Wang L-Y, Salter MW \& MacDonald JF 1992 Regulation of kainate receptors by cAMP-dependent protein kinase and phosphatase. Science 253 1132-1135.

Whitfield JF, Isaacs RJ, Chakravarthy BR, Durkin JP, Morley P, Neugebauer W, Williams RE, Willick G \& Rixon RH 1994 C-terminal fragments of parathyroid hormone-related protein, PTHrP-(107-111) and (107-139), and the N-terminal PTHrP(1-40) fragment stimulate membrane-associated protein kinase C activity in rat spleen lymphocytes. Journal of Cellular Physiology 158 $518-522$.

Wu TL, Vasavada RC, Yang K, Massfelder T, Ganz M, Abbas SK, Care AD \& Stewart AF 1996 Structural and physiologic characterization of the mid-region secretory species of parathyroid hormone-related protein. Journal of Biological Chemistry 271 24371-24381.

Wysolmerski JJ \& Broadus AE 1994 Hypercalcemia of malignancy: the central role of parathyroid hormone-related protein. Annual Review of Medicine 45 189-200.

Received 10 March 1999

Revised manuscript received 30 June 1999

Accepted 22 July 1999 